\title{
Kenneth David Jackson. Adverse Genres in Fernando Pessoa. New York: Oxford University Press, 2010.
}

In Adverse Genres in Fernando Pessoa, Kenneth David Jackson proposes a new understanding of Pessoa's approach to literary genres. The study highlights the centrality of the figure of paradox in Pessoa's works, which, as demonstrated, has also permeated the criticism of his texts. Jackson revisits influential conceptualizations of Pessoa and his heteronyms, such as Octavio Paz's "the man who didn't know himself," Jorge de Sena's "the man who never was," or George Monteiro's "empty labyrinth" of his inner-being. To these Jackson adds his own productive critical metaphors, such as a hypothetical "literary asylum" of "non-beings," a "literary academy" with the atmosphere of a "gentleman's club," or a "literary orchestra" of which Pessoa is the conductor, performer, audience and critic (6).

Common denominators between all of these metaphors are the fragmentation of being, the implausibility of a coherent modern individual self, and the modernist rejection of any biographic understanding of literary production. These metaphors also suggest that Pessoa's poetic voices both complement each other, if seen as an entire literature, or contradict each other, if we expect a coherent esthetic language amongst them. The latter hypothesis is designated in Jackson's study as "adverse authorship" (11). It is pertinent to mention here Pessoa's methodological proposal to himself, in a text likely from May 1915, according to Jerónimo Pizarro (the document $144 \mathrm{~A}-19$ to $20^{\mathrm{r}}$, transcribed in Sensacionismo e outros ismos. Ed. Jerónimo Pizarro. Lisbon: IN-CM, 2010: 296): “Assim publicarei, sob varios nomes, varias obras de varias especies, contradizendo-se umas ás outras. Obedeço, assim, a uma necessidade de dramaturgo, e a um dever social." The diversity of names, according to this note, expresses the desire of presenting "correntes sociaes oppostas" and the understanding that a single name to express all of them would be a contradiction and a problem, since "a contradicção é uma inferioridade." Moreover, Pessoa states that the theses expressed in his own name are not "mais verdadeiras do que as que publicarei com nomes inventados."

Besides highlighting an "adverse authorship," Jackson proposes as the central thesis of his book the figure of "adverse genres" in Fernando Pessoa's works. 
The concept of adverse genres corresponds here to the idea that the poet's voices take up different genres so as to challenge them with "incongruent and inauthentic content, subverting the familiarity of generic expression" (16). The thesis is very pertinent since Pessoa seemed to have a fluid approach to literary genres. I would recall here, for example, Pessoa's provocative claim that to "write good prose a man must be a poet, because a man must be a poet to write well at all" (Heróstrato. Ed. Richard Zenith. Lisbon: Assírio \& Alvim, 2000. 191), which may imply that in their differences genres contribute to reinventing each other.

Adverse Genres addresses the best known of Pessoa’s masks. Álvaro de Campos is seen as a main figure in an esthetic of paradox that results from a sense of human failure. Equally important are the ideas of a contradiction between analytical skills and a world of sensations, and of Campos as a barometer for the incapacity to adapt to the overflow of external stimuli of modernity. In Alberto Caeiro, Jackson finds the adoption of an "adverse pastoral," which subverts themes and language of that genre, namely a bucolic nature, through a skepticism that presents "religious ecstasy without transcendence, without metaphysics, and without metaphors" (120). Alberto Caeiro is here by no means a poet of nature or a proponent of Pantheism, since his writings illustrate the incapacity of humans to go beyond their senses and recognize a deity. Equally relevant is the study of Ricardo Reis's "adverse ode," in which Jackson sees a subversion of classical themes through the inclusion of modernist "existential and esthetic perspectives, charged with depersonalization and nothingness" (133). The study of the Book of Disquietude expands on the affinities between Amiel and Bernardo Soares, particularly the reduction of the self to anonymity and depersonalization. For Jackson, the Book of Disquietude illustrates "the disillusion of a generation" through a nihilistic non-adventure, and the metaphysical concern raised by a gap between consciousness and knowledge.

The study delves into facets of Pessoa's production that have received less critical attention. For the first time, a printed transcription of the original in English of "A Very Original Dinner" is made accessible. The story, seen as a meditation on the role of basic instincts and their repression in modern societies, is discussed from a psychoanalytical perspective. A noteworthy chapter is dedicated to "The Anarchist Banker," whose very title consists of a "paradox 
and contradiction" (108). In a compelling reading, Jackson notes that the story is an exercise of logical discourse weaved with "[s]ophism, subversion and subterfuge" (108), and suggests that, besides questioning methods of rational analysis, it problematizes seriously axioms of Western political thought.

Other sections of the volume that cannot be addressed in the space of this review present valuable discussions of Pessoa's Message, The Mariner, Cancioneiro, and the letters to Ophelia Queirós. The study is invariably supported by an extensive review of scholarship, and often brings in late nineteenth and twentieth-century creations in literature, music or painting that effectively assist in defining a background for Pessoa's writing.

Adverse Genres in Fernando Pessoa guides the reader through a stimulating study of Pessoa's diversity and modernity, to which it easily applies Jackson's image of "mirror within a labyrinth" (184), since the poet's discussion on identity is mostly seen here as motivated by a gap between existence and consciousness. The theory of adverse genres provides an interpretation to Pessoa's strategy of overcoming - often with humor-what Jackson sees as essentially tragic conflicts, such as the "self without being" and "content separated from form," and converting these ontological tragedies into art (180). The new insights and framework offered vastly succeed in contributing to a better understanding of Fernando Pessoa's centrality in international literary modernity.

\section{Ricardo Vasconcelos}

University Wisconsin-Milwaukee 